\title{
Diversity and regional inequalities: Assessing the outcomes of the Spanish 'system of health care services'
}

Guillem Lopez-Casasnovas ${ }^{1}$, Joan Costa-Font ${ }^{2,3}$ and Ivan Planas ${ }^{1}$

${ }^{1}$ Departament d'Economia i Empresa, Universitat Pompeu Fabra, Barcelona.

${ }^{2}$ Departament de Teoria Economica, Universitat de Barcelona, Barcelona.

${ }^{3}$ London School of Economics and Political Science, London.

Contact author: Professor Guillem López Casasnovas. Departament d'Economia i Empresa. He acknowledges additional financial support in this research field from SEC2003-05045/ECO. E-mail: guillem.lopez@upf.edu 


\begin{abstract}
The consolidation of a universal health system coupled with a process of regional devolution characterise the institutional reforms of the National Health System (NHS) in Spain in the last two decades. However, scarce empirical evidence has been reported on the effects of both changes in health inputs, outputs and outcomes, both at the country and at the regional level. This paper examines the empirical evidence on regional diversity, efficiency and inequality of these changes in the Spanish NHS using cross-correlation, panel data and expenditure decomposition analysis. Results suggest that besides significant heterogeneity, once we take into account region-specific needs there is evidence of efficiency improvements whilst inequalities in inputs and outcomes, although more 'visible', do not appear to have increased in the last decade. Therefore, the devolution process in the Spanish Health System offers an interesting case for the experimentation of health reforms related to regional diversity but compatible with the nature of a public NHS, with no sizeable regional inequalities.
\end{abstract}

Keywords: health expenditure, devolution, National Health System, regional inequa lities, Spain. JEL: H7, I38, H31. 


\section{Introduction}

Universal access and an important devolution process of health care to the Spanish regions (Autonomus Communities, $\mathrm{AC}$ from now) are the main features of an evolving public health system during the last 25 years. Although universal access to health care to all Spanish citizens was formally defined in the 1978 Constitution and articulated in the 1986 the General Health Bill, it was until 1999 that general taxation finance ultimately substituted payroll taxes [1]. Despite some political turbulences, since 1981, a gradual process of devolution of health care, initiated in Catalonia and the Basque Country and completed for all the AC in January 2002, has been going on. As a result, health care reforms in Spain diven by cost-containment purposes have run in parallel to those transcendental changes. However it has hardly been undertaken thereafter any assessment on what the health system buys and its value. Prior studies do not fully take into account existing regional heterogeneity, regardless of being one of the k-factors for policy innovation in health care. Persisting questions in the analysis are the influence of changes in increasing efficiency by improving accountability and cost containment as well as in xhieving (or not loosing) equity and social cohesion [2-5].

Spain is indeed a widely heterogeneous country due to economic, cultural as well as political grounds [1]. Accordingly, a devolved model of welfare governance was designed at the onset of democracy whereby health care and education became the core of the Spanish fiscal decentralisation. The Spanish health system has followed a process of 'asymmetric devolution' started in 1981 and concluded in 2002. Only five Autonomous Communities (AC) - Catalonia and Galicia plus some other aiming for a higher self-governance status as Valencia, Canary Islands and Andalusia- were from the beginning 'politically accountable' for health care and two other ACNavarra and the Basque Country - have been in addition 'fiscally accountable' in accordance with their historical statutes. The remaining ten new-branched AC have had very limited health care political and fiscal responsibilities, being centrally managed by the National Institute of Health (Instituto Nacional de la Salud, INSALUD) today practically abolished. In 2002 devolution was completed and at present all AC enjoy full health care responsibilities, although still with limited fiscal capacity, whilst the so called- Cohesion and Quality Law passed by in 2003 states the need of strengthening geographical equality of health protection as well as quality of care. 
In its fundamental conception, devolution aims on the one hand to better serve specific health care demands and regional preferences [3-5]. On the other hand, concerns on this regard refer to the potential for an uneven geography of welfare given the split of responsibilities jointly with lack of information and coordination of the central government among regions [6]. However, scarce empirical evidence has been reported on the effects of devolution - and policy innovation- in health inputs, outputs and outcomes, both at the country and at the regional level in Spain.

This paper tries to cover this gap by examining the empirical evidence on regional diversity, efficiency and inequality in the Spanish system of regional health services, often named as National Health System (NHS). We undertake empirical analysis using cross-correlation, panel data and expenditure decomposition analysis. Results suggest that although the existence of significant heterogeneity, once we take region-specific needs and bring to light efficiency improvements, inequalities in inputs and outcomes do not seem to have increased over time due to decentralisation. Consistently with other studies we find that there is no clear-cut evidence that devolution bring regional inequalities [3-4]. Furthermore, unlike previous studies [6], we argue regional asymmetry is determined not only by supply conditions but by need, what in turn may well enhance an effect in the heterogeneity of regional health expenditure. Therefore, increasing political accountability leads to the fulfilment of region-specific conditions and demands and in turn, improves the NHS efficiency.

The structure of this paper is as follows. First we provide a basic description of the health system, its structure and expenditure trends and determinants. Section three looks at evidence on efficiency while section four examines evidence on clinical outcomes and equity both at the individual and regional level. Section five examines non-clinical outcomes. The paper concludes with a discussion section. 


\section{Description of the system, finance, expenditure and challenges}

\subsection{Health system goals}

The Spanish National Health Service (NHS) might be envisaged as one of the most dynamic European health care systems in the last half century. In the early 1940s the health system was based on means test and covered around one fifth of the population, which expanded to almost half by 1960 and thanks to significant investment, coverage was roughly $80 \%$ by the mid 1970s. Although democracy and the 1978 Constitution defined citizens' rights to health care it was with the General Health Bill in 1986 passed by under the socialist government that health care adopted lines of a universal and decentralised NHS. Central and regional governments have put into force extended coverage and fostered the implementation of health care reforms on a decentralised basis. Finally, the conservative party ended in 1999 the gradual transition process towards a full general tax revenues financing regime and concluded in 2002 the decentralisation process of health care to all the Spanish regions (previously only just the historical regions managed health care). All this has been achieved in less than three decades.

At any rate and purpose, health care is currently the foremost policy responsibility of the AC - jointly with education accounts for $60-70 \%$ of total funds managed by AC. The transfer of health responsibilities to Catalonia was completed in 1981, followed by Andalusia (1984), the Basque country and Valencia (1988), Galicia and Navarre (1991), the Canary Islands (1994) and from 2002, the rest of AC have been empowered with health care responsibilities. Furthermore, the design if AC leads to heterogeneous regions in size which ranges from less than three hundred thousand millions population up to over seven millions inhabitants. Regardless, the central state goals of uniformity amongst - historically and culturally- different AC in self-governance aims have lead to a so-called 'coffee-for-all' decentralisation. Under this new scenario, central responsibilities on health policy coordination are pursued from scratch by the Spanish Department of Health, following the premises of the Health Quality and Cohesion Act of 2003.

Although health care is legally defined as an "essential public service" jointly with education, it is difficult to find the precise content of the health care entitlement as well as an explicit definition of NHS goals, both at the state and at the regional level. As stated in the 1986 General Health Care Act, the NHS is expected to work towards both health promotion and illness prevention, by providing 
health care to all residents in Spain, and achieving equality of access as well as to help to overcome social and geographical differences. Efficiency is blurredly defined and just very recent concern buried by 'financial sustainability' goals. Therefore, the assessment of policy-goal adequacy is unavoidably normative and not always informative.

Access to health care is free at the point of use to all residents (including illegal immigrants) and user co-payments are restricted to pharmaceuticals. In 2002 funded less than $8 \%$ of public drug expenditure in 2002. Benefits are comprehensive although coverage for some services such as longterm care and dental services is limited and varies according to region-specific demands ${ }^{1}$. While basic legislation is in principle issued by the central state, certan common decisions draw upon the input of the Inter-Territorial Council of the NHS -an advisory committee comprising representatives from the central and regional governments- where coordination, as legally defined, must take place. Central governance of the NHS is formally undertaken by the Ministry of Health $(\mathrm{MoH})$, although in some critical domains the Ministry of Social Security - still the owner of the buildings- and the Ministry of Finance exercise remarkable responsibilities. As a result, the $\mathrm{MoH}$ can be classified as comparatively weak, bearing in mind the shared responsibilities with other ministries at the central level, and the strength of regional ministries after the devolution process. A synthetic (empirical, according to the observed rules and financial flows) definition of the NHS Spanish NHS is provided in Figure 1.

\section{[Insert Figure 1 about here]}

\subsection{The system structure}

Health care delivery is mainly undertaken through a network of publicly owned, staffed and operated inpatient and outpatient centres, with significant geographical differences in the way services are contracted out to the private sector. Although access is free, one sixth of Spanish purchase supplementary health insurance, mostly in richer urban areas as a means for 'waiting lists

\footnotetext{
${ }^{1}$ Unlike most of AC, the Basque Country and Andalusia cover child dental care. Similarly, whereas long-term care is defined as a public responsibility in some regional basic statutory Law (e.g., Cantabria, Castilla-La Mancha), in some other regions it is defined as an individual responsibility publicly supported (e.g., Catalonia).
} 
avoidance' in elective care, hospital amenities and prompt access to 'soft' private health care [910]. Non-transparent waiting lists counterbalance tight (particularly in the last decade) NHS budgets, playing the role of actual 'implicit prices'.

Primary care in Spain has progressively moved towards a better-integrated public system, geographically organised in 'health zones' and managed at the level of the 'health area' covering 50100 thousand inhabitants. As a result of the success of the integration of primary care in the late eighties in the NHS network, the population affiliated to a primary care physician was $91 \%$ in 2000 and the number of GP consultation has risen from 5.4 in 1994 to 6.1 in 2002 partly for prescription purposes. Ambulatory care is organised in Health Care Centres (average time per GP consultation is 6.6 minutes), where most of GPs and specific specialists work full time with a basic salary payment and a civil servant status position (instead of former capitated part-time doctors). However, capitation formulas are progressively re-introduced in financing primary care albeit limited by the fact that doctors are salaried and finance does not account for specialist referrals nor drug prescription costs (except in the case of Catalonia and Valencia for some geographical areas).

A gate keeping system was formally set up in 1986 so that patients are asked to pursue GP referral to visit the specialists unless they make use of the emergency care. Interestingly, the former is the fastest growing item of expenditure, together with drugs, of the Spanish Health system. Spain has a surplus of health professionals, which doubles the UK ratio. However, public-private practice compatibility helps the depressed relative wages of active physicians, $70 \%$ employed in the NHS. Freedom of choice of primary care physicians within the same health area and some basic ambulatory specialists is allowed, but no much exercised.

\section{[Insert Figure 2 about here]}

Reforms in health care provision in Spain have lead commonly to the development of regional agencies for health care purchasing with a semi-autonomous status (commonly public corporations) brought away from the Health Departments. Catalonia and the Basque country first instituted a sort of independent public body to coordinate the public coverage function while decentralising the purchasing at health care areas. A benchmark for this is split between pubic provision and public and private (non profit) production of health care in Catalonia where more than 
half of the hospital activity publicly finances 'non Social Security owned beds' (see Figure 2). The implementation of a purchaser provider split in Catalonia had sound meaning, as almost two thirds of hospitals were private (non-profit) and as a result purchasing services from private sector hospitals were comprehensively integrated with few exceptions. A weighted health care unit (UBA) was designed by the Catalan system to measure hospital activity and reimburse hospitals, which was finally adapted by the Spanish Ministry of Health. During the mid nineties, Andalusia and the Basque Country introduced a semi-prospective payment system with DRG case-mix adjustment and Catalonia implemented in 1998 a new tool for paying hospitals that combined payment of both structure (approached by 'Grade of membership' classification Techniques) [58] and activity (DRGmeasured). In the nineties, INSALUD implemented a contractual system with the development of activity indicators and contracts tended to be linked to the regional health plans to improve efficiency.

The Spanish hospital network is made up of approximately 800 hospitals largely dispersed among AC. With the exception of Catalonia, where just $36 \%$ of total beds are provided by public hospitals, the system is predominantly integrated (approximately $68 \%$ being publicly owned) although contracting out implies about a $15 \%$ of public expenditure (see figure 2). The majority of the staff is salaried employees and hospital payment has moved from retrospective to quite-prospective payment systems. Spain displays one of the lowest EU rations of hospital beds/1000 inhabitants. The average length of stay is about 9 days and the bed occupancy rate roughly $80 \%$. The number of beds per 1000 inhabitants is 3.9 and inpatients admissions. Interestingly, the ageing process places its effects as the most frequent age cohort; whereas in 1982 discharges of people among 75 were $6.6 \%$ in 1998 they were $17.59 \%$. Trends exhibit a reduction in acute beds and a small rise of long term care centres. From 1997 some few public hospitals are self-governed and from 1999 some other public hospitals have become independent agencies. This has caused trade unions complaints on differences on wage and working conditions, although there is no evidence on the effects of these changes on hospital performance yet [18].

Along with primary and inpatient care, the NHS funds $92 \%$ of the total pharmaceutical expenditure. Density of pharmacies is comparatively small and paid under margin basis. Regulation is based on a relatively recent reference pricing system although the weak generics penetration still limits its effectiveness in reducing expenditure. Other services are long term care and dental care. 
Long term care coverage is limited and mostly means tested, regulated at the AC level and provided at the local level. Public home care is narrowly promoted (4\% of total supply) and the involvement of the public sector financing in residential care is about $6.9 \%$ of total expenditure. Integration of health and social care is the prime difficulty, as far as social care is a responsibility of the social security and local authorities while regulation is regionally issued [18]. Dental care is mainly provided by the private sector with the exception of some minor procedures (e.g., extractions). However, some regions have started to include coverage for dental care for children under a certain age (12 years) in their regional health care packages.

Private health care plays a complementary role for the NHS when it does not provide coverage for certain services (e.g., dental care), fulfils the demand for quality of care (hospital hotel facilities and waiting list avoidance in primary care). Moreover, private provision is substituting NHS coverage, financed by public funds, for some civil servants, at no additional cost (see figure 2). The share of the population with these schemes shows a steady rise pattern from 1987 (12\%) to 1992 (14.5\%) leading to $15.5 \%$ in 1997, and losing relative share at present (not in monetary terms given the constant increase in premiums. Up to 1999, a 15\% tax relief in the personal income out of total private health expenditure was directly promoting private expenses on health care, including the purchasing of private health insurance and excluding luxury treatments (e.g., plastic surgery when this was not included in public benefits, or spa treatments).

\subsection{The resource allocation system}

Funds are centrally collected -with the exception of Navarre and the Basque Country and some minor taxes for the remaining regions. Before 2002, the system has operated under a single central transfer. Once the Spanish Parliament determined the amount of health care expenditure in the National General Budget, expenditure was allocated to regions by means of a block grant according to a mostly unadjusted capitation formula. Although fiscal autonomy has been progressively increasing - by transferring 15 per cent of the personal income tax revenues collected in each AC in 1992, which later was raised to 30 per cent in 1997 plus a $20 \%$ surcharge on the personal income tax -, the vicious cycle of overspending (prevalent as normal practice both before and after devolution process) remained. The reasons for this included the lack of incentives to cut expenditure and the scarcely transparent bilateral agreement between the AC and the central state. 
In 1994, the government unsuccessfully committed expenditure growth rates to GDP increases and imposed tighter conditions on extraordinary resources, by defining full regional responsibility for any overspending. However, this later provision was not credible due to the limited regional fiscal autonomy and regional political pressures for larger social spending. Furthermore, the distribution of funds depended on a quasi-capitation formula based on population size, barely taking into account demography, population density, or morbidity and mortality factors. In fact, the formula did not place its effects due to the establishment of a supplement to compensate those regions which decreasing ppulation and supplementary contributions for teaching and research and for crossboundary flows were improved.

By 2002, a deeper structural reform was implemented, ending with the split of regional health care finance from the rest of the regional transfers, by inserting health care funding in the general regional resource allocation system. The new allocation formula weights the following features: population $75 \%$, demographics (population over 65 ) $24.5 \%$ and insularity $0.5 \%$, remarkably no health indicators are present yet [7-8]. Furthermore, the agreement includes regional participation in the revenue of most of the centrally collected taxes - with the exception of the corporation income tax- with open-ended margins for complementary fiscal regional autonomy. In particular, the funding system comes out in fixed proportion from personal income taxation actually collected in the AC (35\%), VAT (40\%) and taxes on petrol (40\%) -both according to the estimated regional percentage of consumption-, and some other minor taxes (at 100\%: specific tax, inheritance, property transfer and taxes on gambling). In addition, a new retailer petrol tax, earmarked to fund health care, may be optionally introduced by AC. Territorial equity is pursued by the set up of three mechanisms: a 'cohesion fund' to compensate cross boundary flows, a 'sufficiency fund' to ensure a minimum financial capacity and 'an equalisation fund' to contain regional diversity. In order to preserve cohesion by avoiding 'excessive' deviation in per capita health spending amongst regions, central transfers will help those AC that show increases in public health coverage (say due to legal immigration) three points above the Spanish average.

\subsection{Decentralisation and competition structure}


The decentralised design of a NHS is often grounded on the expected efficiency gains both in the production and allocation of resources, larger incentives for policy innovation, better responsiveness to citizens' demand and greater political accountability. However, conflicts refer to the extent to which a NHS should limit 'regional diversity' resulting from differences in funds and resources. Ideally, a decentralised NHS should define the "minimum" set of benefits and implicitly enable regions to develop additional coverage at the expense of their own fiscal effort, thus transferring risk management to regions. Heterogeneous health expenditure might then result only from differences in clinical practices and central priorities in health care allocation from the past. No margins for regional autonomy in finance were allowed. Therefore, the (inter-regional) competition structure of the Spanish NHS before 2002 promoted political accountability better than fiscal accountability. This has changed after 2002; a floor on health expenditures is established, but regional resources can add up to the former amount according to the evolution of total regional finance and parliament priorities in health care.

Generally speaking, responsibilities in regional health provision have markedly developed as a "learning by doing" process [4] which appears to foster positive externalities, basically in improving health care delivery [7] and thus fuelling health care expenditure which in turn casts some doubts on the sustainability of the health care funding. Moreover, inter-regional patient flows are negligible to promote horizontal competition structures and regional responsibilities for health care are still sensibly unclear in many areas. Therefore, regions have strong incentives to vertically compete with the central state for the regulation and funding of regional health services by undertaking policy innovation [4]. In this setting the health system objectives may arguably need to be accommodated. Furthermore, due to the political visibility of health care policy, innovation has been horizontally disseminated (in the form of positive spillovers) to other regions through a process of policy imitation, thus it is likely that inequalities both in inputs but especially in outcomes may not increase over time.

Before 2002, AC funds were the result of a political bargaining between the central and the regional Departments of Health. However, after 2002, the bargaining will be shifted between Finance Ministers first and secondly, at the regional internal level, between the regional expenditure ministers within each AC. The regional parliaments will now have a more decisive ultimate word on heath policy issues. If we add to this a larger discretion of regional funding - based on own regional taxes, surcharges of central taxes and revenue sharing of central taxation- we should expect to open 
the floor for resource allocation diversity in the future. The central state requirements is a minimum departure amount (defined by regional expenses at the point of transfer), a minimum rate of increase centrally determined given the revenue increases plus an extraordinary vertical levelling fund, to be implemented in future according to the differential evolution of the population covered by the regions. Finally, a Cohesion Fund to be funded by the central budget -so far with a low starting amount will devote resources to subsidise cross boundary flows of patients amongst regions.

Some caveats exist on how the central state will compensate for new central regulations or pricing policies (new drugs to be reimbursed, and centrally authorised new health technologies among other) that affect regional expenses. A defined basic entitlement package will become a necessity if patients are not to exploit differences. Diversity itself should not be a cause for concern, provided the basic minimum package is covered, any additions are financed from regional sources and a perequalisation system exists in order to match basic expenditure needs and regional fiscal capacity. Handling other variations in policy, such as those applied to drugs, may not be straightforward. Although regions will not negotiate drug prices by themselves, they may well influence the prescribing habits of their professionals. This will pose new challenges to the marketing departments of drug companies.

\subsection{Trends in expenditure and expenditure determinants}

Health care expenditure accounts for 7.5 per cent of the GDP with approximately three quarters (5.5 per cent) corresponding to public expenditure and a quarter (2.1 per cent) to private expenditure (see Table 1). Furthermore, health care accounts on average about 40 per cent of regional expenditure, although health expenditure relative to regional GDP varies from $3.6 \%$ Balearic Islands to $7.5 \%$ in Extremadura. Individuals can supplement the NHS by purchasing private health insurance (PHI), covering mainly primary care and hospital amenities on fixed providers' list [9-10].

\section{[Insert Table 1 about here]}

One of the most recurrent issues in examining health systems refers, indeed, to whether the NHS is over (under) financed and how health care expenditure evolves with income. Spain's share 
of health spending in 1980 was one of the smallest among other European NHS (Table 2) and it remained practically unaltered along the eighties until 1988 that it went up to $6.1 \%$, surpassing the UK and equalling Portugal the year after, Ireland (6.4\%) in 1990 and surpassing Finland in 1995 (7.7\%). From then on, it remained practically constant. Thus, in the last two decades there has been a steady increase in the per capita resources devoted to health care. Spain expends more than Finland (7.7\%), Ireland (7\%) and the United Kingdom (7\%) at the time they had the same GDP per capita that Spain has today. Moreover, on the basis of our calculation, income elasticity during the eighties (1980-1989) was 1.31, during the first nineties (1990-1995) rose to 1.84 and the last nineties (1996-2000) dropped to 1.24. Therefore, from this simple analysis it cannot be concluded that health care in Spain behaves as a luxury good.

\section{[Insert Table 2 about here]}

When examining health expenditure layers, main highlights are that whereas inpatient care increased significantly during the eighties, in the nineties relative expenditure decreased, mainly thanks to contracting out systems, as well as reforms in the primary care sector (see data on Appendix A1-A2). From the first nineties we find that about 55\% is spent on inpatient and specialised care, $16 \%$ is devoted to primary care, research and public health account for $4 \%$, and pharmaceuticals have been steadily rising from $18 \%$ in mid nineties to $23 \%$ in 2002 . Outpatient expenditure remained stable, always lower than 1\% of the GDP. During the period 1986-1992 relative pharmaceutical expenditure raised $40 \%$. The average costs by receipt, due to the progressive reduction of effective co-payments from 1980's, reflect this feature. Interestingly, due to the co-payment system, the share of public pharmaceutical expenditure by pensioners has raised steadily being $39.2 \%$ in 1980, and almost twice at present. Prevention still represents a negligible magnitude $(0.1 \%$ of the GDP) remaining constant across the period. Expenditure on personal was moderately around $45 \%$ of the GDP during the eighties, however after the implementation of the primary care reform and the regional devolution of health care, it went up to the $7 \%$.

Prices in the health sector have been slightly higher than those in the rest of the economy though the differential was not increasingly wide. Therefore, other determinants are behind the health expenditure rise. They include health care coverage, the ageing process and especially significant changes in utilisation patterns. Although there is some methodological debate [11-13], 
evidence from prior studies [14-15] highlights that whereas during the period from 1980-1986 prices where the main driver of health expenditure, from 1987 onwards it was utilisation what pushed health expenditure to increase. The ageing process and the coverage played all over the period a marginal role. In this study we have followed the decomposition methodology discussed in those previous studies [15]. Although there were considerable differences in health care prices among AC, 1995 and 1999 were the years where the share of real utilisation was higher (see Appendix A3). The effect of ageing was larger in Catalonia, Canary Islands and Murcia and price changes were significantly uncoordinated among AC. Finally, a fixed effects panel data model looking at the determinants of public health expenditure at the regional level highlighted that the income elasticity for the period 1992-1999 was close to unity. As expected, ageing, measured as the dependency ratio, pushed up expenditure and population displayed a negative coefficient showing some evidence of scale effects (see Appendix A4).

Alongside public expenditure, the composition of private health care expenditure has significantly shifted from 1980 to 1995 [16-17]. Dental care mostly not covered by the NHS, accounted for $17 \%$ of private expenditure in 1980, increased in 1990 (30\%) and accounted for $27 \%$ of total private expenditure latter on. In contrast, the progressive reduction in pharmaceutical copayments (effective co-payment was about 18\% in 1980, declined to 11\% in 1990 and in 2000 is about $8 \%$ ) lead to out-of -pocket drugs expenditure to decline its share of private health expenditure from $36 \%$ in 1980 to $18 \%$ in 1990 and $27 \%$ in 1995. Out-of pocket medical care declined in the eighties from $22 \%$ to $13 \%$, mainly due to the extension of primary care and the expansion of public coverage and then remained roughly constant until 1995. Finally, private health insurance coverage went from 14 to $11 \%$ between 1980 and 1995, growing less rapidly from 1992 onwards when five regions achieved health care responsibilities.

Once we introduce the regional dimension of the system performance, we find that remarkable features pointing out significant cross-regional differences in the expansion of the private sector. Following the Leviathan hypothesis, we should expect private health expenditure rises due to the devolution process. However, existing evidence suggests an ambiguous effects pointing out a somewhat reversal effect [4]. Overall, the decline of total real health expenditure was $31 \%$ in devolved regions and $16 \%$ in INSALUD regions. However, per capita total (and public) health expenditure was larger in the two fiscally as well as politically accountable regions (Navarre and the 
Basque Country). Comparing data from 1990-1998 from the Continuous Household Survey we find that private health expenditure in real terms increased by three times in INSALUD regions such as Aragon (14\%), Murcia and Castilla-Leon (1\%) although in some regions with devolved responsibilities such as Andalusia (11\%), the latest due to the weak role of private sector before decentralisation. The main increases of real private expenditure were in some $\mathrm{AC}$ run at the time by INSALUD such as Balearic Islands (90\%), Cantabria (20\%) and Asturias (22\%).

\section{Efficiency}

\subsection{At the macro level}

Compared to other NHS countries, Spain ranks in a middle situation in health spending, once health expenditure is regressed on GDP it places in the exact point of the fitted line. In terms of overall performance it is fifth in the WHO table. This suggests that 'good value for money' seems then to be achieved at the aggregate level. In the past, health care reforms have tended to focus on cost-containment - mainly by defining positive and negative drug lists - but hardly ever there is an explicit assessment on what the health system buys. Cost containment goals lead to the definition of the basic package of benefits covered by the Spanish NHS. This was defined as distinguishing primary care, specialised care, pharmaceutical benefits and finally complementary benefits (i.e prostheses, orthopaedic products, etc). As a result of this definition, some benefits were implicitly excluded from coverage, such as some mental health treatments and diagnosis tests (psychoanalysis and hypnosis) and dental care (although Navarre and the Basque Country do provide some additional coverage), sex-change treatments (explicitly covered in Andalusia), regular health checks or plastic surgery. The (implicit) package does not include social nor community care. Some low therapeutic value drugs are excluded too (in this case in an explicit way).

\subsection{Organisational Innovation}

The Spanish system may be briefly characterized for the former purpose as follows: 
(i) Physicians are civil servants, with salaries defined homogeneously in annual central budgets, with protected employment for life and a sense of clinical autonomy evidenced by unjustifiable variations in clinical practice.

(ii) Administrators of the health units have to manage resources under the limitation from restrictive administrative rules to control fraud and with tentative budgets that are retrospective, according to the capability of the manager facing the funder.

(iii) Patients/ citizens have a small sense of commitment to the health authority or community, other than to their local doctors.

In Spain the efforts for changing the present situation include

1- The introduction of a variable component in wage payment of physicians according to productivity (ultimately incorporated linearly into the basic salary);

2- A purchase-provider split with Program Budget Contract (Insalud since1992), which has proved to be illusory when provider and purchaser are both public agents (under centralized retrospective budgets);

3- Free choice of doctors by patients, in some cases with the 'ratchet effect' that, under salaried primary care physicians' systems, this has meant lower work load without lower remuneration;

4- More 'accurate' payment systems for hospitals based on 'needed' activity, with the illusion that 'worse' (more activity) prognoses are 'better' for the institution;

5- And of course, organizational change.

\section{The Catalan mirror}

Catalonia, with 6 million residents, a strong sense of autonomous community and concern for self-governance, runs as commented its own health care services and offers a variety of initiatives for organisational reforms. Municipalities, Churches, and private wealth endowments-or the so called 'civil society'- in social care, complement the initially poor public health care network. At present, the majority of hospital care services are provided by a publicly financed network of hospitak, with $60 \%$ of the beds out of social security management. Most of these hospitals (16 important ones) are 'public consortia' of territorial interests (municipalities and provinces), open to private non-profit participation. In addition, some private foundations are also licensed for public provision. This allows health authorities to take advantage of the situation by contracting out on the 
basis of hospital activity instead of just reimbursing actual expenses. No discrimination between patients is formally possible within the Public Network and in practice, risk selection has never been an issue to-date, despite the fact that the four largest and more complex hospitals are social security hospitals and capable of dealing with patients with more severe illness.

In Catalonia, consortia and foundations work under their own management rules. These are rather different from the administrative common constraints of the remaining Spanish social security institutions. Indeed, the employment policies, managerial charts and internal operating rules of the hospital consortia are defined by the principle on which they have been created (or changed afterwards by common agreement). This reflects in (i) the way they purchase inputs (following private law); (ii) how they contract professionals (out of the civil servants regime) and set their working conditions (more flexible, with in and out-of-hospital greater compatibility of public-private practices if convenient); (iii) the capability to create pure private instrumental organizations for achieving the consortia interests (provision of care for private insurers).

With more autonomy, they own their assets, their finances are publicly controlled ex -post and not ex -ante, and they are governed by representatives of the community subject to a lower degree of political influence. So far, their management has proved to be robust to political changes. The 'associated group of interests' is usually chaired by a member of the local community with no direct involvement either in politics or in the health care business.

In a similar way, Hospital Foundations (8 important ones) are actually private organizations given the rules on which they operate, but under a public protectorate. Their governing body is commonly open to representatives of the civil society who risk their reputation and assume legal responsibilities for the privilege of leadership. Foundations own their assets and operate under the private law in all the aspects of their activity. They may borrow freely in the private market. If they are contracted out by the Catalan authority, given their non-profit status, they need to be licensed and monitored by the public regulator in a similar way as consortia are.

In addition to this, in the organization of Primary Care services, The Nationalist Party, which has been in power for more than 20 years in Catalonia has also avoided opening new Health Area Teams under the old administrative rules. Fourteen experiments are run currently with selfemployed physicians, either under 'Co-operative' organizational forms or Limited Responsibility 
Corporations for well-delimited geographical Health Areas. These new teams are financed on capitation grounds, with some elective inpatient care usually being included, and with notional agreements on drug prescription costs. This means in reality that primary care in these new areas is just 'indirectly' publicly managed. These health areas have being awarded a license (recently open to free choice of different providers) and they decide on working conditions, budget surplus, incentives on peer controls and salaries. They offer a more extended working hours and some of them offer community premia or direct prices for some additional services (minor, so far), out of the public 'catalogue' (such as some treatments for dental care, podiatry, etc.).

Co-operatives and Organizations on a Voluntary Basis (Limited Responsibility Co) can be created by professionals of the NHS. The assets of these organizations, at least in a $51 \%$ have to be in hands of these professionals. None of them may own more than a $25 \%$, and share-holding is prohibited for Co-operatives. Physicians who accept a change in status from the former social security primary care teams to the new forms do not lose their job in the public system for a certain period but they do not have their particular post 'reserved.' These organizations are subject to private law, they own their own assets, sometimes financially supported indirectly by the Royal College of Physicians, which offer a sort of leasing contract to professionals willing to assume some financial risk and managerial autonomy. Needless to say those physicians who have left the old regime are a biased sample, since they are usually more committed to the public provision of health care (no private practice is there), have greater motivation (they are young) and are probably tired of the old rules in which 'someone from outside tells you what to do, and you get the same payment irrespective of the effort you put into the team'.

Finally, during the last three years, the Catalan Health Authority has offered, on a voluntary association basis, a capitation regime to 5 larger regions (7\% of the Catalan population). This provides new organizational frameworks for health care integration on a regional basis. In this context, several providers with diversified status, different organizational forms, different positions in primary, hospital and long term care integrate their equipment and co-ordinate strategies for fulfilling the Catalan Health Plan's objectives with a larger sense of autonomy. No loss of finance comes out of reducing activity, a more efficient co-ordination of primary and hospital care, inpatient versus outpatient care or ambulatory surgery, or by reducing the costs of prescription drugs, since they are 
financed on a risk-adjusted population basis. Despite the fact that extending the system to the large metropolitan area of Barcelona seems impossible, the first evaluation results recently published by the Generalitat of Catalonia are encouraging. At any rate, this new Catalan pilot experiment on capitation follows the strategy of not creating hierarchically-uniform health providers; awards greater autonomy to providers (extended internally within their institutions); and pushes for a better co-ordination of health care facilities and health strategies in what they achieve in terms of health outcomes.

\section{The Spanish experience}

The Spanish version of the efforts for implementing organizational changes in health care are limited up today to Foundation Hospitals for new hospitals and the so called 'Hospital Public Foundations' for the already existing hospitals. Given the lack of tradition and the absence of political commitment on these proposals both remain in 'limbo': just four in all the Spanish geography for the first, and zero for those of the second type.

Indeed, following the existing general Law for the Creation of Private Foundations (1994), the Spanish Government passed in 1996 a bill for the creation of new small to medium sized hospitals. These are all public foundations that have adopted the existing private regulation for foundations in trying to escape from the public administration rules. These rules allow employment of staff according to general labor legislation, purchasing supplies under private law, and less intervention by allowing ex -post control of expenditure, private accountancy rules, etc. However, public and private are mixed and confused in practice. For instance, the 'Protectorado' (the supervisory body) and 'Patronato' (the administration body) are both under the same hands (to-date Insalud, the central health authority). There is not a separate endowment for Foundation expenses (the equipment, which results from the public investment) and in deciding current revenues, the financer sits on all the management boards, appointing managers and representatives in the 'Patronato'.

This was the case up to January of 2002 when INSALUD ran health care for 12 autonomous communities with no regional transfers since it was reluctant to open the governing bodies of these hospitals to regional or local Authorities with different political colour. This has had 
the side effect of putting private foundations in the political debate, not just by those claiming that this leads to the privatisation of health care, but also by others for partisan reasons.

Today, all the Regional Authorities run health care in Spain, and it is interesting to observe that despite past criticisms, neither changes in hospital status nor seats on the governing boards have occurred in the existing Foundations. They are probably here to stay, although we still do not have a well accepted evaluation of Hospital Foundations. At any rate these Foundations have raised expectations for change, which would be ruined if no support were shown in the future. More highly motivated, better paid doctors with less private practice and access to new equipment shape a new type of public management culture beyond this organizational change.

Finally, specific legislation for Public Foundations was introduced in the Budget Law in 1999, under strong political disagreement of medical trade unions and parties in opposition. The changes did not affect, in any case, the pre-existing employment rights and had to be accepted on a voluntary basis by health professionals. Finally, some changes in the Conservative Party put all the efforts of the former Minister of Health, after a large and sordid political debate, in a closed box. Today, these type of Foundations sleep also in the 'limbo' of the Spanish Health Reform.

\subsection{Evidence from efficiency studies}

Unlike other countries, there is no systematic independent public review on the efficiency of health care organizations in Spain. Non-systematic exceptions are the reviews undertaken by the Society for Public Health and Health Services Administration (SESPAS) and the regular surveys from the Annual meetings of the Spanish Health Economics Association (AES). Since 2003 an Observatory of the Spanish Health System is reporting on the evolution of the main health care indicators on a regional basis.

In the managerial arena the so called Top-20 Report on Spanish Hospitals, includes an evaluation of 140 hospitals on voluntary bases although questioned in what regards the information systems employed and the exclusive focus on production rather than access and need [20]. The latest attempts to capture the evolution of the efficiency in the Spanish health care system [20-21] focus on relative measures of efficiency in hospitals and primary health care, along with factors 
explaining variations in efficiency levels and changes in total factor productivity. Here we distinguish studies on hospital and primary care efficiency.

Generally speaking efficiency studies are not commonly standardised in the international arena, and neither they are in Spain. Therefore, here we revise those that offer results with significant policy implications [18, 22-37]. Some evidence using frontier models suggests that privately funded hospitals improve allocative efficiency better than public and non-for profit hospitals [24] and among these more diversified hospitals were relatively more efficient [25]. Other studies using the Malmquist index [26-28] find a reduction on factor productivity over the period 1993-1995 although a more recent study based on a 1995-1999 sample [29] reveals remarkable productivity increases in the later period (1995-1999) in Andalusia. A cross comparison between the Basque country, Catalonia and Andalusia [30] finds that most efficient hospitals are those exhibiting a larger size and those displaying the highest number of nurses per bed. Studies on the efficiency of INSALUD hospitals suggest that the major cause of allocative inefficiency is the excess of labour in the cost composite [31] as well as hospital size and those contracting out certain health care inputs. At the organisation level, studies on hospital efficiency in Catalonia highlight a direct relationship with scale and complexity. Some other studies point out that teaching hospitals are less efficient than the others [32] that a major cause is the excess proportion of highly qualified professionals [33-34]. Least efficient INSALUD hospitals are those with high activity, low diversification, low-tech capital, but at least one specialty department [35]. Remarkable results suggest that a potential reduction on waiting lists could follow from a better control on the length of stay [36]. Finally, contracting out is identified as a major cause of relative technical efficiency $[\mathbf{1 8}, \mathbf{3 7}]$.

Efficiency studies in primary care should be treated with some caution as far as almost all studies used Data Envelopment Analysis and hardly ever de al with allocative efficiency. Results of the studies vary from a technical efficiency of 0.73 or 0.87 for PC teams in Madrid [38], 0.51 in Aragón [39], 0.87 in Navarre [40] and 0.91 in Catalonia [41], thus exhibiting important regional variation in technical efficiency. More recently some data came from the evaluation of the organisational innovations in Catalonia, showing better results than those for the old civil servants regime. Better indicators were in the New Teams of GPs for the average waiting time for a visit (less that one day in a $40 \%$ of the cases, $68 \%$ in 2 days), for a better access to paediatric care after 
$5 \mathrm{pm}$ (children leave the school at this hour), more continuity in health care (by overlapping working schedules along the day) with indicators of satisfaction for this three times higher for the new teams than for the traditional forms. Similar good indicators for the new organisational forms against the old ones refer to a lower utilisation of antibiotics for some common viral flu (11\% of the cases against $31 \%$ ) and for gastroenteritis ( $6 \%$ of the cases against $17 \%$ ). Some adjustment is needed before assessing the meaning of lower prescription costs, despite similar total costs per capita/year, of lower referrals (22\% of the cases against $33 \%$ ) and a lower number of visits per inhabitant year $(5.3 \% \text { against } 6.8 \%)_{[58]}$.

Indicators measuring clinical quality of care reveal ambiguous results. The share of caesarean section over all obstetric deliveries suggests a rise from $17.3 \%$ in 1993 to $21.7 \%$ in 2000 . Surgical activity displays a significant raise from 7 interventions per 1000 inhabitants in 1995 to 16.4 in 2000. However, the number of transplants undertaken has increased from 1488 in 1993 to 2032 in 2000.

In assessing performance of hospital organisational diversity in Catalonia, it appears that the cost of activity, case-mix adjusted, of these Hospital Foundations is clearly below that of the largest social security hospitals. This has reflected lower salaries for their staff, which in turn reflect more flexible working conditions. Hospital Consortia and Hospital Foundations are widespread in Catalonia and their status and community representation has proved resistant so far to changing political forces in the local constituencies.

In the primary health care arena, evaluation of the changes in Catalonia performed by The Donabedian Foundation for Quality Assessment and the Royal College of Physicians of Barcelona have offered first evaluations of the experiments with rather satisfactory results either on health care access, efficiency and local citizens' satisfaction. This is basically linked to a more continuous access to the teams (open after five o'clock) and the sense of membership of an innovative group with new equipment, with respect to those units managed by the Catalan Institute for Health (the majority of primary care teams). More specifically, new organisational in novations in Catalonia, against the old civil servants regime show better indicators were in the New Teams of GPs for the average waiting time for a visit (less that one day in a $40 \%$ of the cases, $68 \%$ in 2 days), for a better access to paediatric care after 5 pm (children leave the school at this hour), more continuity 
in health care (by overlapping working schedules along the day) with indicators of satisfaction for this three times higher for the new teams than for the traditional forms. Similar good indicators for the new organisational forms against the old ones refer to a lower utilisation of antibiotics for some common viral flu (11\% of the cases against $31 \%$ ) and for gastroenteritis (6\% of the cases against $17 \%$ ). Some adjustment is needed before assessing the meaning of lower prescription costs, despite similar total costs per capita/year, of lower referrals (22\% of the cases against $33 \%$ ) and a lower number of visits per inhabitant year $(5.3 \% \text { against } 6.8 \%)^{2}$.

Of course all these changes involve some potential risks still not confirmed in practice (higher transaction costs, violation of some minimum risk pools, cultural values against profit incentives and budget surplus in health care provision) and create a political response by those who prefer the old system and accuse the Catalan government of privatising health care. Since public finance and public regulation are maintained, these claims are difficult to sustain. The absence of non profit bureaucratic provision does not mean that a preference for consumers or social goals is absent, since consumer surplus may be lost by larger production costs under pure public production. Limited for profit incentives do not mean patients' welfare exploitation by producers when free choice and non-territorial monopolies are present. Furthermore, the job of the regulator needs to be more responsive and alert because its mistakes will be more apparent than the mistakes on hierarchical ruling of public organizations.

In short, despite the fact that the Catalonian Health System can show a rather successful record in institutional innovations in health care, organizational change is a very limited strategy for health care reforms in public systems. It is not a surrogate for the necessary clarification of the extent of the private sector involvement in public health care, nor a substitute for an open discussion on its adequate mix of public and private finance.

\subsection{Micro-efficiency and regional heterogeneity}

\footnotetext{
${ }^{2}$ Fundacion Avedis Donabedian. 2003. Mimeo for The Catalan Health Service
} 
Several layers as the rise of relative health care prices, adoption of "expensive" new technologies and health care intensity influence efficiency. Therefore, an issue to examine is whether there are significant differences in health care resources across AC, especially capital and labour inputs and technology available. Beginning by capital, Cantabria (5.7) and Catalonia (5) display the highest number of beds by 1000 population, while Andalusia (3.26) and Valencia (3) have the smallest rate. This reveals that differences in the beds rate by 1000 inhabitants cannot be regarded to decentralisation; the coefficient of variation (CV) was the same across all regions. However, significant differences were found in the public-private fix of beds, $82 \%$ of beds were in publicly owned INSALUD hospitals in contrast to $32 \%$ in Catalonia. Hospital infrastructure evidence shows that only $20 \%$ of hospitals in Catalonia are public (46\% are general hospitals, $5 \%$ mental hospitals and 30\% are nursing homes) and one third in Basque Country (58\% are general hospitals, 16\% mental hospitals and 18\% nursing homes), Balearic Islands (72\% are general hospitals) and Madrid (44\% are general hospitals, 12\% are mental health hospitals and $10 \%$ are nursing homes). In the last three, about two thirds of the beds were provided by public institutions, indicating the presence of small private centres.

Despite differences in size, there are significant differences in hospital specialisation. Commonly, the richer the AC is, the larger the number of small and specialised hospitals. Regarding labour inputs Navarre and Madrid concentrate the largest physician density, as they are areas with large activity and huge hospitals whilst poorer AC concentrate less physicians. Once more, heterogeneity cannot be regarded to devolution as inequality within INSALUD regions was higher that the rest. Nurse density rate was higher for AC with devolved responsibilities. An additional source of regional heterogeneity is technology equipment. Catalonia, Madrid, Valencia and Andalusia concentrate more than $50 \%$ of equipment in hospitals.

When examining the rate of technology we found that X-Rays are highly used in the Basque Country (0.64) and La Rioja (0.61) whereas in Madrid or Galicia showed a lower use. These come out not only from differences in availability but from variations in clinical practice. Navarre and Basque Country have higher use of Computerised Axial Tomography. Madrid, Navarre and Balearic Islands show higher rates of Nuclear Magnetic Resonance and Andalusia, Castilla y Leon and Murcia exhibited higher rates of homodynamic rooms' use. Interestingly, INSALUD regions experience a higher variability than the rest. The same applies to gammographies and digital 
angiographies. Rates of biopsies are similar across the two types of AC, but again some regions as Galicia and Murcia show three times higher rates than Balearic Islands and Canaries.

Decentralisation in the nineties brought to significant reduction in the length of stay in Andalusia (33\%), Basque Country and Catalonia (23\%) and a rise in the number of patients treated and the level of health care contracted-out [42]. Activity indicators show significant regional heterogeneity and display higher variability when compared to INSALUD regions. The average length of stay in the whole country reduced from 9.2 in 1992 to 7.61 in 1999. Regional heterogeneity is 8 or less in Balearic Islands, Andalusia and Valencia while about 12 in Canary Islands and Castilla Leon. Occupancy rates are over $80 \%$ in Catalonia, Cantabria, Canary Islands and the Basque Country whereas about $75 \%$ in Andalusia, Balearic Islands and La Rioja. Rotation and substitution do not significantly vary across AC. The use of urgency care (the share of urgencies from total consultancies) is large in Catalonia and Balearic Islands while Canary Islands and Galicia and INSALUD regions showed less variability that the rest.

There is very little evidence on the variability in clinical practice in Spain and most of it is very recent [43]. Evidence shows that inter-regional differences in hospital attendance are small although there is variability when accounting for specific processes [44-46]. In fact, surgery intervention heterogeneity is higher than the one found between regions. However, when specific studies are examined, we find that that cataract's interventions range from 4.3 per 1000 inhabitants (Galicia) to 9.8 in Catalonia or 9 in Andalusia, Basque Country and Extremadura. The same applies to prostate intervention (benign hyperplasic) where ratios vary from 5.6 per 1000 in Aragón, Valencia or Murcia to 11.2 in Catalonia or 10.4 in Rioja (Company et al, 1995). The implications of clinical variability are large, a study [47] finds that over a set of 20 interventions, if the cheapest practice would have been implemented across the NHS, this would imply saving 16 additional million euros a year.

\section{Inequality}

\subsection{Health outcomes and avoidable mortality}


As other developed countries, Spain has experienced a very significant improvement in health during these decades (Tables 3 and 4). In 2000 the mortality rate was about 9.35 per 1000 inhabitants. Life expectancy in Spain is 75.6 ye ars in males and 82.9 in females in 2001 and has experienced a steady increased 5.46 years since 1975 . Consequently, this has brought a rise in the share of the elderly, now being $15 \%$ of the population and is expected to rise $39 \%$ in the next thirty years. In Spain the baby boom started a decade later. As Costa et al [56] highlight, life expectancy in 2002 was higher both in males and female than Germany, Italy and the UK. However, life expectancy is subject to regional heterogeneity as well being the highest in Castilla-Leon (76.3 in male and 83.2 in female) and Madrid (75 and 83 respectively) and the lowest Balearic Islands (73.2 and 81.1) and Andalusia (73.5 and 80.7) for both male and female. Navarre (4\%) and the Basque Country (3\%) improved their life expectancy in the eighties when they were not yet politically accountable for health care. From 1990- 95 there seems to be a convergence in life expectancy growth at a $1.2 \%$.

\section{[Insert Table 3 about here]}

\section{[Insert Table 4 about here]}

Table 3 highlights that, indeed, Spain is a heterogeneous country in health outcomes, although the coefficient of variation is not large for most of the indicators available. Interestingly, this table suggests that by distinguishing those regions with devolved responsibilities from those traditionally centrally managed does not result significant difference in health outcomes. Looking at avoidable mortality as termed in Spain [48], Table 3 reports estimations on avoidable age-gender standardised premature mortality for 1998. Estimates suggest that although there is a north-south pattern, not related to regional health care expenditure, some regions as Catalonia perform better in both measures of premature mortality whereas some others Basque Country expedience low mortality for health policy related diseases and large mortality for health service related diseases.

\subsection{Socio-economic inequalities in health and health care}

An important issue when examining the impact of health care system reforms in NHS countries is the effect of specific policies on influencing social cohesion and the extent in which the 
health system reduces the barriers to health care of the most disadvantaged. Several studies, testing whether position explains health care utilisation, controlling by social reed, show that there have been considerable variations in inequality indicators of health care delivery. Data for 1987 showed that inequalities in the delivery of health care are moderately 'pro-rich' [49]. However, more recent studies [50-51] using health surveys from 1987-1997 find small inequalities in access to health care When examining inequalities in health outcomes, several studies evidence that there is a socioeconomic vector which explains differences in adjusted mortality, prevalence and self -reported health status [52]. Finally, regarding progresivity of health expenditure, around a quarter of total financing refers to indirect taxation (which is well known to be regressive) and the remaining financed through direct taxes. The combination of both sources shows that the financing system has become less progressive [53].

\subsection{Inter-regional health and health care inequalities}

Devolution often raises concerns on the impact of diversity on social cohesion. From 1986 to 1999/2000 patterns of interregional inequalities in per capita health expenditure describe a nonmonotonic trend where the Coefficient of Variation (CV) rises up to a value of 0.13 where there is no significant difference between AC with devolved and non-devolved responsibilities (Figure 3). Furthermore, some inequality appears in how health systems manage their outpatient and impatient expenditure. Inequalities in mortality and potential years lost seem to evolve following a similar pattern between AC regardless health care responsibilities. Furthermore, INSALUD regions show slightly larger inequalities in avoidable mortality in 1998 both in health care $(\mathrm{CV}=0.22)$ and health policy $(\mathrm{CV}=0.19)$. The same applies when the coefficient of variation is computed for inpatient doctors. No statistically significant correlation was found between inequalities in health expenditure and inequalities in health outcomes indicators. The CV of physicians working in hospitals decreased from being 0.26 in 1980 to 0.24 in 1990 to vales of 0.14 in 1992 and 0.12 in 1995 . Inequalities within INSALUD regions again were larger. The correlation between per capita health expenditure and inequalities in resource physicians' availability was 0.082 ( $p>0.05)$. Regional inequalities in health care have shown to be positively correlated with per capita health expenditure $(r=0.71, p<0.05)$ whereas no statistically significant correlation coefficients were identified with regional inequalities in mortality for all AC. The same applies for only those regions with centralised health care responsibilities, although the correlation coefficient between inequalities in that case is larger $(\mathrm{r}=0.92$ 
$\mathrm{p}<0.01$ ). Inter-regional inequalities in health (measured in terms of mortality and potential years of life lost) show a similar declining pattern among regions and when the correlation coefficient was never significant from 1992 to 1999.

\section{[Insert Figure 3 about here]}

The 'other face of the toss' concerns the territorial equity of NHS funding. To these end, a so-called distribution vector is obtained as the difference between the allocation of revenues and spending benefits among $\mathrm{AC}$ [53]. This highlights the extent to which specific regions contribute to fiscal redistribution more than its income. Interestingly, Catalonia and Balearic Islands are the ones distributing that should receive more, taking into account their income, and with a different extent (due to the 'capitality of the State' factor) are followed by Madrid. In the other extreme, there is Navarre, Extremadura and Andalusia that receive far more of what they contribute. The explanation for this falls in that Navarre has a special fiscal status and Andalusia and Extremadura are the poorest Spanish AC in terms of income per capita. Conversely, Catalonia and Balearic Islands are among the richest and are not fiscally accountable (with the exception of small taxes).

\subsection{Intra-regional health inequalities}

Other than focussing on inter-regions inequalities, one of the largest concerns is the existence of intra-regional disparities. We do not have generally good studies on the estimation of intra-regional disparities and their determinants. Geographic patterns of mortality seem to highlight some spatial distribution of mortality linked to the variation in social and environmental feature. Small areas so-called "zones" where constructed in this purpose to study the distribution of the comparative mortality ratio (CMR) [54]. Out of eight AC with ratios above 100, six were located in the south of Spain. However, by examining the difference between the maximum CMR and minimum it is found that the largest difference is in Valencia and Canary Islands and the smallest difference is identified in La Rioja, Navarre, Asturias and Cantabria. Therefore, it can be argued that large inequalities within small areas of specific AC still remain. Other dimensions of intraregional inequalities refers to differences in resources, being the lowest in the Basque Country $(\mathrm{CV}=0.16)$ what could be attributed to the significant rise in public inpatient care and the success in 
extending the primary care reform. The opposite apply to Catalonia with high variability in outpatient care $(\mathrm{CV}=0.6)$ where the primary care reform was slower.

\subsection{The association between inputs, outputs and outcomes}

Available data (1985-1999, table 5) do not show any positive correlation between expenditure per capita and relative supply of beds $(r=-0.05 p>0.05)$ nor with physician concentration $(r=0.32 \mathrm{p}>0.05)$, length of stay (LOS) $(r=0.02 \mathrm{p}>0.05)$ and occupancy rate $(r=0.07, p>0.05)$. However, there seems to exist a positive association with the utilisation of certain health technologies, in particular with the use of Computerised Axial Tomography $(r=0.64, r<0.01)$, and Digital Angiographies $(\mathrm{r}=0.39, \mathrm{p}<0.1)$. Interestingly, it appears a positive association with quality of care: a negative significant correlation coefficient is identified $(r=-0.53, \mathrm{p}<0.05)$ when expenditure per capita is correlated with surgical infections. However, when several indicators were tested to examine whether there was any correlation between health (mortality, life expectancy, neonatal and prenatal mortality) and health expenditure, none of them displayed a significant correlation coefficient.

A positive correlation between relative supply of beds and physician concentration is found $(r=0.6, p<0.1)$. As expected, we find a positive association between length of stay (LOS) and the bed occupancy rate $(r=0.78, p<0.05)$. Interestingly, the higher the relative supply of beds, the higher the $\operatorname{LOS}(\mathrm{r}=0.71, \mathrm{p}<0.05)$ and the higher is the occupancy rate $(\mathrm{r}=0.67, \mathrm{p}<0.05)$. In addition, we find a negative association between rotation and $\operatorname{LOS}(r=0.92, \mathrm{p}<0.05)$ and occupancy rate $(r=0.56$, $\mathrm{p}<0.05)$. Finally, we examined the correlation coefficients between several health care indicators and resources and we found the following. First, female life expectancy was both associated with supply of beds $(r=0.60 . p<0.01)$ and physicians $(r=0.68, p>0.01)$. The number of beds was negatively correlated with infant mortality $(r=-0.61, p>0.01)$, neonatal mortality $(r=-0.68, p>0.01)$ and perinatal mortality $(r=-0.44, p>0.05)$.

Although acknowledging the limitations of a cross-correlation analysis, there is no easily identifiable pattern on morbid-mortality factors capable to be located on a geographical basis and related to regional differences in health care inputs. However, as expected there is an association between technology and input availability with expenditure. Results suggest, by comparing trends in 
expenditure, utilisation and outcomes a the regional level, before and after the decentralization process, that differences in health care inputs are not systematically reflected into differences in outcomes. These are mostly related to within regions health related policies and not to the existing (minor) financial variation of resources amongst regions.

\section{Citizens' perceptions and satisfaction}

There is not much information about non-clinical dimensions of quality in Spain. The exception to this rule refers to satisfaction surveys which are contentious to interpret to the extent that might not evolve with real NHS developments. Roughly speaking, Spain occupies a middle-low position compared to other EU member states [55-56]. Interestingly, the Spanish health care barometer surveys provide evidence on satisfaction layers. Satisfaction with non-clinical quality dimensions of the system was higher for the Basque Country and Navarre as well as Valencia. INSALUD as a whole and Andalusia are generally on the Spain's average whereas Catalonia and Canary Islands stand slightly below. Overall, people appear to be significantly satisfied with proximity of health care centres. Nevertheless, between 1986 and 1990 NHS satisfaction dropped continuously especially in satisfaction with the hospital sector. However, a recent survey for 2002 shows that about $50 \%$ is satisfied both with hospital and ambulatory care are perceived to have improved in the last ten years and the NHS obtains roughly a score of 6 out of a maximum of 10. Persistent problems are waiting lists especially in outpatient specialist visits as well as in impatient non-urgent care. Interestingly, citizens seem to be satisfied with the proximity of primary care centres and the treatment they receive from practitioners: $80 \%$ of those surveyed could remember the name of the practitioner. More than $50 \%$ of citizens perceive differences between urban and rural areas (Table 6). With regards to decentralisation $38 \%$ perceive that this has improved health care quality while $33 \%$ thinks that nothing will be changed

\section{[Insert Table 5 about here]}

Choice as a non-clinical outcome has traditionally conferred a low priority by public authorities. However, some AC have introduced the free choice of GP (Andalusia, and Catalonia within PC teams), a maximum waiting time before allowing patients freely to access to private practice publicly financed in Castilla-La Mancha, and several provisions on this respect have been 
approved both at the regional and central levels during the 1990s such as the possibility of a second specialist advice in Canary islands and later exported to other regions, and the set up in the early nineties of the freedom of choice of GP within urban areas for the 10 INSALUD AC.

Other two issues that deserve some analysis are responsiveness and accountability concerns on citizens and patient acceptance of the NHS. Health care is the main priority for Spaniards jointly with housing and education. The analysis at the regional level of the representative surveys (Barometro Sanitario) highlights that health care is the main priority in 12 out of 17 AC. The vast majority of the population believes that the system needs minor changes, being the Basque Country and Navarre the AC where most of the population agreed on that the system was working well or needed minor changes. Balearic Islands and Canary Islands, receiving a large amount of tourists a year, being those $\mathrm{AC}$ in which a larger share of population perceives that significant changes are needed.

Decentralisation and the set up of a democracy in Spain can qualify as the two main issues that have influenced the most the political accountability. The Centre for Sociological Research (CIS) provides data on responsiveness suggesting that during the nineties $66 \%$ disagreed on paying more taxes and believed that it was possible to maintain the services by reducing taxes for public services but about the same percentage agreed from 1987-1998 that the government was responsible for welfare. Finally, a reducing share of $11 \%$ agrees on taxing for redistribute purposes.

\section{Conclusions}

This paper draws on examining the developments of the Spanish NHS during the last two decades whereby devolution and NHS consolidation have simultaneously taken place. Although 'ideal data' is not always available, this study find comprehensive evidence pointing out that Spain has sought to decentralise the health system without weakening inter-regional social cohesion. We have focussed our study in examining regional diversity, efficiency and inequality in the Spanish NHS. Results suggest that regardless of significant heterogeneity, once we take into account regionspecific needs; there is evidence on innovations for efficiency improvements whilst inequalities in inputs and outcomes do not seem to have increased over time at the state level. Therefore, regional diversity in the Spanish universal NHS does not seem to be promoted at the expense of geographical 
inequalities. Moreover, decentralisation of health care to regions has helped to break a more central monolithic bureaucratic pattern and spill financial pressures over more politically and fiscally more accountable regions. In doing so, devolution has proven to drive policy innovation.

In the light of these results, we argue that in order to promote quality improvements a ke y issue may be to develop decentralisation further up to the clinical level. The Spanish Health System offers an excellent field for continuing experimenting reforms to improve health care delivery. At the current stage, challenges for health policy in Spain refer to four key points: improving information systems for a better coordination such as it is required for the integration of health care and this with social care at a geographical level; redesigning the system of incentives to promote providers networks; improving public participation through the involvement of local authorities at large in health care provision and setting up performance management objectives more closely related to the main population health targets [59].

\section{References}

[1] Rico, A and Sabes, R. Health Care Systems in Transition: Spain. European Observatory on Health Care Systems, 2000

[2] Benach, J and Urbanos, R.M. Evaluación del objetivo de equidad en salud. In Informe SESPAS, 1999.

[3] Powell, M and Boyne, G. The Spatial strategy for Equality and the Spatial Division of Welfare. Social Policy and Administration, 35: 181-194, 200.

[4] Rico, A and Costa-Font, J. Power rather than path? The dynamics of health care federalism and the building of the Spanish NHS. Journal of Health Policy, Politics and Law 2004 (forthcoming).

[5] Rico, A and López, 2003 Lopez-Casasnovas, G. Devolution of health care in Spain to the regions becomes a reality. Eurohealth 8 (3): 36-38, 2002.

[6] Giannoni, $M$ and Hitiris,T. The regional impact of health care expenditure: the case of Italy. Applied Economics 34 (14): 1829 - 1836, 2002.

[7] Lopez-Casasnovas G, Rico A. Decentralization: part of the health system problem or the solution? Gac Sanit. 2003 Jul-Aug;17(4):319-26

[8] Lopez-Casasnovas, G. Devolution of health care in Spain to the regions becomes a reality. Eurohealth (2002) 8 (3): 36-38.

[9] Costa, J and Garcia, J. 'Demand for Private Health Insurance: How Important is the Quality Gap?' Health Economics 12: 587-599 (2003).

[10] Jofre-Bonet, M (2000). Public health care and private insurance demand: the waiting time as a link. Health Care Management Science, 3: 51-71

[11] López Casasnovas, G .1998. Financiación autonómica y gasto sanitario público en España. Papeles de Economía Española., 76: 2-14. 
[12] Barea $\mathbf{J}$ et al. Análisis económico de los gastos públicos en sanidad y previsión de los recursos necesarios a medio plazo. Instituto de Estudios Fiscales. $\mathrm{M}^{\mathrm{o}}$ de Economía y Hacienda. Madrid. 1993.

[13] Blanco A. and de Bustos A. El gasto sanitario público en España: Diez años de Sistema Nacional de Salud. April 1996. Working Paper Dirección General de Planificación. Ministerio de Economía y Hacienda. Madrid

[14] López- Casasnovas, G and Casado, D. La financiación de la sanidad pública española: aspectos macroeconómicos e incidencia en la descentralización fiscal. Presupuesto y Gasto Público 20/1996 123-152

[15] Pellisé, L., Truyol, I., Blanco, A. and Sánchez-Prieto, F. Financiación sanitaria y proceso transferencial, G.López-Casasnovas (ed.) In La evaluación de las políticas de servicios sanitarios el Estado de las Autonomías. Análisis comparativo de las Comunidades Autónomas del Andalucía, Cataluña y el País Vasco. Bilbao: Fundación BBV e Institut d'Estudis Autonomics. 2001.

[16] Murillo, C. and González, B. El sector sanitario en España. Situación actual y perspectivas de futuro. Hacienda Pública Española 1993; 41-58.

[17] Martínez, E. Las deducciones en el IRPF por gasto sanitario privado: situación actual y posibilidades de reforma. Papeles de Economía Española 1998, 76: 273-283.

[18] González, B. and P. Barber. Changes in the efficiency of Spanish public hospitals after the introduction of program-contracts, Investigaciones Económicas 1996, XX,3:377-402.

[19] Casado D. and López Casasnovas G., Vejez, dependencia y cuidados de larga duración. Colección de Estudios Sociales 2001. Fundació La Caixa.

[20] Peiró S ¿Son siempre odiosas las comparaciones? Gestión Clínica y Sanitaria 2002, 4(2), Editorial: 35-37.

[21] Puig-Junoy, J. Los Mecanismos de Copago en Servicios Sanitarios: Cuando, Cómo y Porqué. Hacienda Pública Española 2001.

[22] Cabasés J M , Martín J J, and López del Amo M P. La eficiencia de las organizaciones sanitarias. Papeles de Economía Española 2003 (95): 195-212

[23] Wagstaff A. Estimating efficiency in the hospital sector: a comparison of three statistical cost frontier models. Applied Economics, 21: 659-672. 1989

[24] Puig-Junoy, J. Ineficiencia técnica y asignativa en la producción hospitalaria: Una aplicación AED-AR. Documento de Trabajo de la Fundación BBV 1999. Madrid.

[25] Prior, D. and Solà M. Technical efficiency and economies of diversification in health care. Health Care Management Science 2000 (3): 299-307.

[26] Carretero, L., C. Pérez, M.P. López del Amo, and J. Martín. Utilización del benchmarking en la evaluación de la eficiencia del Hospital Costa del Sol. Comunicación presentada en la sesión sobre eficiencia. XVII Jornadas de Economía de la Salud, Murcia. 1997.

[27] Navarro, J.L. Internacionalización de las técnicas de gestión sanitaria. PhD Thesis, Universidad de Granada. 1997.

[28] Solà, M. Avaluació de la gestió hospitalària: determinació de les economies de diversificació i valoració dinàmica de la qualitat i la productivitat. Tesis doctoral, Departament d'Economia de l'Empresa. Universitat Autònoma de Barcelona. 1998.

[29] Navarro, J.L. Salarios y eficiencia productiva en hospitales. XXI Jornadas de Economía de la Salud, Oviedo June 6-8. 2001. 
[30] González, B., P. Barber, and J. Pinilla. Estimación de la eficiencia de los hospitales generales de agudos mediante modelos de frontera estocástica, en La evaluación de las políticas de servicios sanitarios en el estado de las autonomías. Análisis comparativo de las CC.AA del País Vasco, Andalucía y Catalunya. Fundación BBV y Institut d'Estudis Autonòmics. Generalitat de Catalunya.1999.

[31] García Prieto, C. Ineficiencia técnica y asignativa en los hospitales del Insalud, Estudios sobre Economía Española FEDEA. EEE 63. Madrid.1999.

[32] López-Casasnovas G. and M. Sáez. The Impact of Teaching Status on Average Costs in Spanish Hospitals. Health Economics 1999, 8: 641-651.

[33] Rodríguez-Álvarez A. La medida de la eficiencia asignativa en una burocracia: El sector hospitalario público español. Tesis doctoral, Universidad de Oviedo 2000, Departamento de Economía.

[34] García C. Ineficiencia técnica y asignativa en los hospitales de Castilla y León. Departamento de Fundamentos del Análisis Económico. Universidad de Valladolid. 2001.

[35] García C. Determinación de la ineficiencia técnica en presencia de ineficiencia asignativa. Una aplicación a los hospitales públicos españoles. XXI Jornadas de Economías de la Salud.

[36] Ventura, J., and González E. Análisis de la eficiencia técnica hospitalaria del Insalud G.D. en Castilla y León, Revista de Investigación Económica y Social de Castilla y León, 1:39-50. 1999.

[37] Dalmau, E., and Puig-Junoy J. Market structure and hospital efficiency: evaluating potential effects of deregulation in a National Health Service, Review of Industrial Organization 13:447-466. 1998.

[38] Badenes, N. and Urbanos R. Análisis de la eficiencia técnica como medida de gestión sanitaria: una aplicación a la atención primaria de salud, en Economía de la Salud, Textos al V Congreso Nacional de Economía, Las Palmas: 243-255. 1995.

[39] Urbina, O. Modelización y medida de la eficiencia en atención primaria. Tesis doctoral. Universidad de Zaragoza.2000.

[40] Goñi, S. El Análisis Envolvente de Datos como sistema de evaluación de la eficiencia técnica de las organizaciones del Sector Público: Aplicación en los Equipos de Atención Primaria, Revista Española de Financiación y Contabilidad 1998, XXVII, 97: 979-1004.

[41] Puig-Junoy, J. and Ortún V. Cost Efficiency in Primary Care Contracting. A Stochastic Frontier Cost Function Approach. UPF Working Paper 2000, Barcelona.

[42] Gonzalez, B et al (2001). Organización y Gestión. In Lopez-Casanovas, G and Rico, A (eds). Evaluación de las políticas de Servicios Sanitarios en el estado de las Autonomías. Fundación BBV, pp 15-233 (Tomo II).

[43] Moya-Ruiz C, Peiró S, Meneu R. (2002) Effectiveness of feedback to physicians in reducing inappropriate use of hospitalization. Int J Qual Health Care; 14: 305-312 and Meneu R. Variabilidad de las decisiones médicas y su repercusión sobre las poblaciones. Colección Economía de la Salud y Gestión Sanitaria. Dir. Vicente Ortún. Ed. Masson. S.A. Barcelona. 2002.

[44] Sarriá A and Sendra JM. Diferencias regionales en la utilización hospitalaria. Gaceta Sanitaria 1993; 7:63-69

[45] Compañ L, Peiró S, and Meneu R. Variaciones geográficas en hospitalizaciones quirúrgicas en ancianos: una aproximación a partir de la Encuesta de Morbilidad Hospitala ria. Revista de Gerontología 1995; 5:166-170. 
[46] Sarria A and García P. Diferencias en la utilización de hospitales en las Comunidades Autónomas de Madrid y Cataluña Gaceta Sanitaria 1996;10:12-17.

[47] Meneu R. Repercusiones económicas de la variabilidad en la páctica médica. En: Necesidad Sanitaria, Demanda y Utilización. XIX Jornadas de Economía de la Salud. Zaragoza: Asociación de Economía de la Salud 1999,383-389.

[48] Ortún V, Gispert R. Exploración de la mortalidad prematura como guía de política sanitaria e indicador de calidad asistencial. Med Clin (Barc) 1988;90:399-403

[49] Rodríguez, M Calonge, S and Reñé, J. Equity in the finance and delivery of health care in Spain. Van Doorsaler, E ;Wagstaff, A and Rutten, F (eds). Equity in the finance and delivery of health care. An international perspective. Oxford University Press, pp 201-218. University Press, New York. pp 31-64. 1993.

[50] Urbanos R. La prestación de los servicios sanitarios públicos en España: cálculo y análisis de la equidad horizontal interpersonal para el período 1987-1995. Hacienda Pública Española 2000, 153-2: 139-160.

[51] Urbanos, R. Measurement of inequality in the delivery of public health care: evidence from Spain (1997). Working Paper FEDEA 2001, 2001-15.

[52] Urbanos, RM (2000). Desigualdades sociales en salud y efectividad potencial de las políticas públicas: un estudio aplicado con datos españoles. Hacienda Pública Española, 154: 217238.

[53] Calonge S and Manresa A. Incidencia Fiscal y del Gasto Público Social sobre la Distribución de la Renta en España y sus CC.AA. Fundación BBV. Bilbao.2001.

[54] Blendon R.J., Minah K, and Benson,JM The Public versus the World Health Organization on health system performance, Health Affairs, vol.20, №3, May-June 2001.

[55] Mossialos, E. Citizens' view on health systems in the 15 Member states of the European Union, Health Economics 1999, Vol. 6, 109-116.

[56] Costa J. Wittemberg R. and Patxot J. The effects of demographic assumptions of long-term care expenditure. In Comas et al. European Study of Long-Term Care Expenditure, European Commission.2002. Brussels.

[57] Vertrees JC., Manton KG. A multivariate approach for classifying hospitals Medi. Care 24: 283- 300, 1986.

[58] Fundacion Avedis Donabedian. 2003. Mimeo for The Catalan Health Service

[59] G.López-Casasnovas (ed.) In La evaluación de las políticas de servicios sanitarios el Estado de las Autonomías. Análisis comparativo de las Comunidades Autónomas del Andalucía, Cataluña y el País Vasco. Bilbao: Fundación BBV e Institut d'Estudis Autonomics. 2001 
Figure 1. An overview of the Spanish NHS and the Catalan Health Service for Comparative purposes

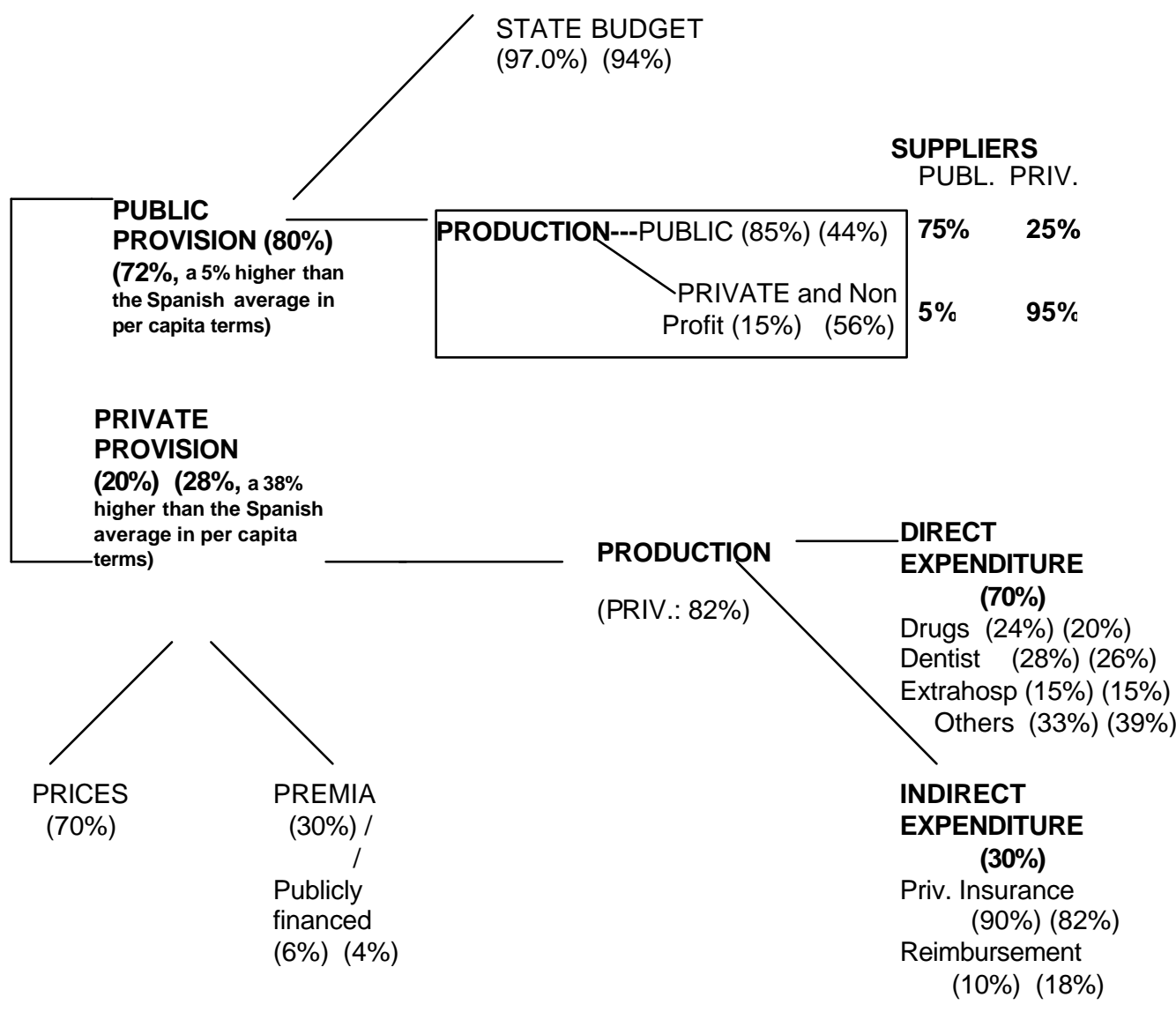

Key words: Finance refers to the revenue sources;provison to the service responsabilities; production, regards to who produces the service; and supply, to the inputs ownership. Prices can be identified with direct expenditure and premia with indirect expenditure. Source: own elaboration, from different sources. In the second bracket, similar figure for the region of Catalonia, with the most different idyosincratic model oh health care. 
Figure. 2

Organizational chart of health care system

\begin{tabular}{|l|l|l|}
\hline REGIONAL PARLIAMENTS (17) \\
* Regional laws \\
* Regional budget law \\
$\begin{array}{l}\text { * Public health } \\
\text { * Manning } \\
\text { healtheare }\end{array}$ \\
Source: HIT of Social Security
\end{tabular}

Figure 3 Inter-regional inequalities in health and health care (Coefficient of variation of public health expenditure and health by $\mathrm{AC}$ )

Impatient and outpatient health Expenditure

Total Health Expenditure

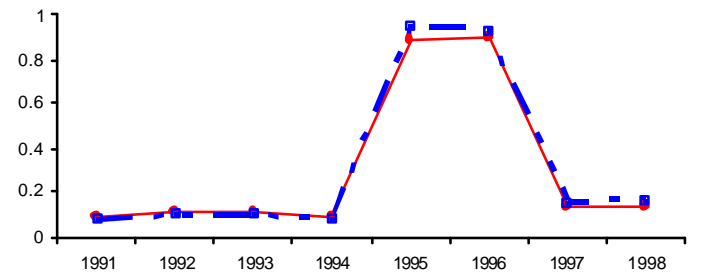

$\longrightarrow$ All —ם- - INSALUD

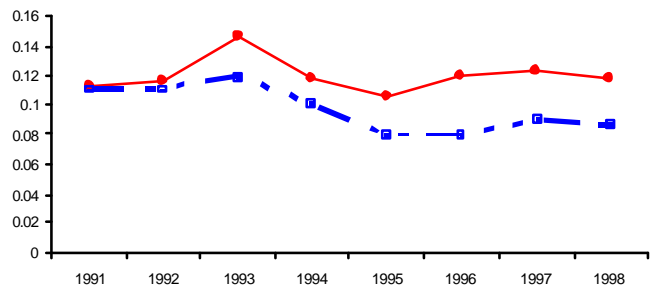

$\longrightarrow$ All —ם- - INSALUD 

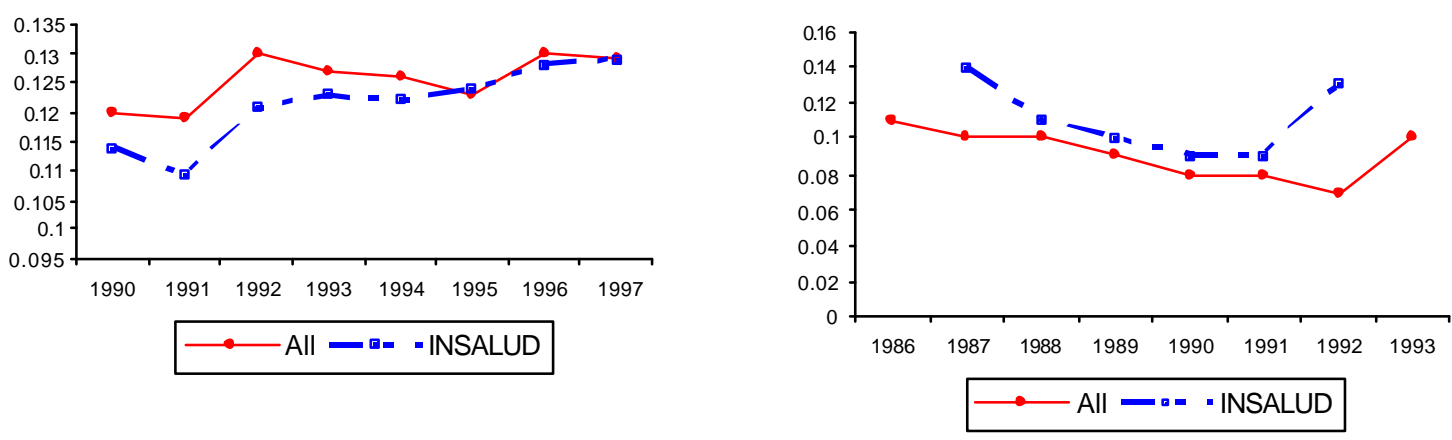

Source: own calculations.

Table 1. Health Expenditure in Spain 1995-2001

\begin{tabular}{|c|c|c|c|c|c|c|c|}
\hline & 1995 & 1996 & 1997 & 1998 & 1999 & 2000 & 2001 \\
\hline \multicolumn{8}{|c|}{ Public Expenditure } \\
\hline Million $€$ & 24,125 & 25,686 & 26,877 & 28,616 & 30,681 & 32,671 & 35,131 \\
\hline$\%$ Total & 72.3 & 72.4 & 72.5 & 72.3 & 72.2 & 71.7 & 71.5 \\
\hline$\%$ GDP & 5.5 & 5.5 & 5.4 & 5.4 & 5.4 & 5.4 & 5.4 \\
\hline \multicolumn{8}{|c|}{ Private Expenditure } \\
\hline Million $€$ & 9,262 & 9,774 & 10,176 & 10,978 & 11,831 & 12,866 & 13,987 \\
\hline$\%$ Total & 27.7 & 27.6 & 27.5 & 27.7 & 27.8 & 28.3 & 28.5 \\
\hline$\%$ GDP & 2.1 & 2.1 & 2.1 & 2.1 & 2.1 & 2.1 & 2.1 \\
\hline \multicolumn{8}{|c|}{ Total Expenditure } \\
\hline Million $€$ & 33,387 & 35,460 & 37,053 & 39,594 & 42,512 & 45,537 & 49,118 \\
\hline$\%$ Total & 100 & 100 & 100 & 100 & 100 & 100 & 100 \\
\hline$\%$ GDP & 7.6 & 7.6 & 7.5 & 7.5 & 7.5 & 7.5 & 7.5 \\
\hline
\end{tabular}

Source: Ministerio de Sanidad y Consumo, 2003.

Table 2: Average annual rate of growth of real health expenditure and of GPD (*) 1978-2001 Spain versus the European Union.

\begin{tabular}{llllll}
\hline & $1978-83$ & $1983-88$ & $1988-93$ & $1993-98$ & $1999-2001$ \\
\hline Spain & $2.4(1.2)$ & $4.8(3.4)$ & $5.7(2.0)$ & $2.4(3.1)$ & $3.5(3.4)$ \\
European Union & $3.1(1.8)$ & $3.7(3.1)$ & $4.0(2.1)$ & $2.7(3.3)$ & $5.3(2.5)$ \\
\hline
\end{tabular}

Source: OECD data file 2003 
Table 3. Health indicators by AC (Life Expectancy, Mortality, Neonatal Mortality, Perinatal Mortality, Premature avoidable mortality by health care and health policy)

\begin{tabular}{|c|c|c|c|c|c|c|c|c|c|}
\hline & $\begin{array}{l}\text { Male } \\
\mathrm{LE}^{1}\end{array}$ & $\begin{array}{l}\text { Female } \\
\mathrm{LE}^{1}\end{array}$ & Mortal. $^{2}$ & $\begin{array}{l}\text { Infant } \\
\text { M. }^{2}\end{array}$ & $\begin{array}{l}\text { Neonat } \\
\text { al M. }\end{array}$ & $\begin{array}{l}\text { Postnatal } \\
\text { M. }^{2}\end{array}$ & $\begin{array}{l}\text { Perinatal } \\
\text { M. }^{2}\end{array}$ & $\begin{array}{c}\text { Premature } \\
\text { M. }^{3}\end{array}$ & $\begin{array}{c}\text { Premature } \\
\text { M. }^{4}\end{array}$ \\
\hline Andalusia & 73.5 & 80.7 & 8.3 & 5.8 & 3.5 & 2.3 & 6.9 & 18.32 & 11.04 \\
\hline Aragón & 75.6 & 82.3 & 10.8 & 3.7 & 2.5 & 1.1 & 4.8 & 19.39 & 6.07 \\
\hline Asturias & 73.1 & 81.3 & 11.8 & 4.6 & 2.8 & 1.7 & 7.3 & 20.90 & 8.45 \\
\hline Balears & 73.2 & 81.1 & 9.3 & 4.6 & 2.5 & 2 & 8.2 & 22,49 & 8.03 \\
\hline Canary I. & 73.8 & 81.3 & 7.1 & 5 & 2.9 & 2.1 & 7 & $22 . .98$ & 10.42 \\
\hline Cantabria & 74.4 & 82.2 & 10.1 & 3.1 & 0.8 & 2.3 & 1.8 & 19.70 & 6.31 \\
\hline Castilla-LM & 76.1 & 81.7 & 9.7 & 5.2 & 3.1 & 2.2 & 6 & 15.08 & 6.03 \\
\hline Castilla Leon & 76.3 & 83.2 & 10.4 & 3.6 & 2.6 & 1 & 4.4 & 22.34 & 5.93 \\
\hline Catalonia & 74.7 & 82.3 & 9.1 & 3.8 & 2.4 & 1.4 & 5.2 & 14.50 & 6.44 \\
\hline Valencia & 74.1 & 81 & 9.1 & 4.5 & 3.2 & 1.3 & 5.4 & 18.28 & 8.06 \\
\hline Extremadura & 74.6 & 81.5 & 9.7 & 4.3 & 2.6 & 1.7 & 5.8 & 24.01 & 7.15 \\
\hline Galicia & 73.9 & 81.8 & 10.6 & 5.2 & 3.1 & 2 & 5.3 & 17.21 & 6.88 \\
\hline Madrid & 75.1 & 83 & 7.4 & 4.2 & 2.3 & 1.9 & 4.3 & 15.05 & 4.17 \\
\hline Murcia & 74.5 & 80.9 & 8.2 & 5.9 & 3.4 & 2.4 & 6.9 & 25.50 & 7.30 \\
\hline Navarre & 75.7 & 83 & 9.2 & 5.5 & 3 & 2.4 & 6.9 & 20.09 & 6.55 \\
\hline Basque $\mathrm{C}$. & 74 & 82.2 & 8.8 & 6.1 & 4.1 & 2 & 6.5 & 19.76 & 6.47 \\
\hline La Rioja & 72.2 & 82 & 9.6 & 5.9 & 3.6 & 2.3 & 7.3 & 19.18 & 5.96 \\
\hline Total & 74.4 & 81.6 & 9.4 & 4.9 & 3 & 1.9 & 5.9 & 19.28 & 7.13 \\
\hline INSALUD & 74.5 & 81.9 & 9.7 & 4.5 & 2.6 & 1.9 & 5.7 & 20.22 & 6.54 \\
\hline CVTotal & 0.01 & 0.01 & 0.13 & 0.19 & 0.24 & 0.24 & 0.26 & 0.17 & 0.24 \\
\hline
\end{tabular}

Source: MSC 2002, INE and own calculation following De Manuel et al (2001) methodology in G.LopezCasasnovas, 2001 [58]. ${ }^{1}$ Life Expectancy in years,2000. ${ }^{2}$ Mortrality Rate per 1000 in $2000 .{ }^{3}$ Premutaure Rate per 10,000 in 1998 (health care related) ${ }^{4}$ Premutaure Rate per 10,000 in 1998 (health policy related)

Table 4. Life expectancy by age gender and AC

\begin{tabular}{lllll}
\hline & 1980 & 1990 & 1995 & $1999^{*}$ \\
\hline Females at birth - Years & 78.6 & 80.4 & 81.5 & 82.4 \\
Females at age 65 - Years & 17.9 & 19.1 & 19.8 & 20.5 \\
Males at birth - Years & 72.5 & 73.3 & 74.3 & 74.9 \\
Males at age 65 - Years & 14.8 & 15.4 & 16.0 & 16.4 \\
Total at birth- Years & 75.6 & 76.9 & 77.9 & 78.7 \\
Andalusia & 74.5 & 76 & 76.9 & 77.46 \\
Canary Islands & 74.2 & 76 & 77.3 & 77.6 \\
Catalonia & 76.9 & 77.3 & 78.2 & 79.1 \\
Valencia & 74.9 & 76.3 & 77.2 & 78 \\
Galicia & 75.2 & 76.6 & 77.8 & 78.8 \\
Navarre & 75.3 & 78.1 & 79 & 79.9 \\
Basque C. & 75 & 77.2 & 78 & 79 \\
INSALUD-10 & 75.5 & 77.24 & 78.15 & 78.9 \\
\hline
\end{tabular}


Source : MSC, 2002 *Data on AC life expectancy refers to the latest from 1998.

Table 5. General opinion on the NHS 1993-2003 ( $\%$ of responses)

\begin{tabular}{ccccccccc}
\hline & 1993 & 1994 & 1995 & 1997 & 1998 & 1999 & 2000 & 2002 \\
\hline Works well & 19.8 & 17.1 & 20.1 & 20.2 & 19.9 & 21.8 & 21.6 & 18.6 \\
Works well but needs changes & 32.8 & 36.6 & 40.7 & 41.3 & 43.1 & 44.7 & 46 & 48.2 \\
Needs fundamental changes & 29.5 & 31 & 28.5 & 29.2 & 28.4 & 25.4 & 25.8 & 27.6 \\
Needs re-making & 17.9 & 13.8 & 9.8 & 7.8 & 7.3 & 6.7 & 6.5 & 5.6 \\
\hline \multicolumn{7}{c}{ Source: Ministerio de Sanidad y Consumo, 2003 } \\
\hline
\end{tabular}

\section{Appendix}

Table A1. Relative and per capita health expenditure in Spain 1980-2001

\begin{tabular}{ccccccc}
\hline & $\begin{array}{c}\text { Total exp. } \\
\text { on health } \% \\
\text { GDP }\end{array}$ & $\begin{array}{c}\text { Total exp. } \\
\text { on health / } \\
\text { capita, US\$ } \\
\text { PPP }\end{array}$ & $\begin{array}{c}\text { Public exp. } \\
\text { on health } \% \\
\text { GDP }\end{array}$ & $\begin{array}{c}\text { Public exp. } \\
\text { on health / } \\
\text { capita, US\$ } \\
\text { PPP }\end{array}$ & $\begin{array}{c}\text { Private exp } \\
\text { on health } \% \\
\text { GDP }\end{array}$ & $\begin{array}{c}\text { Private exp } \\
\text { on health / } \\
\text { capita, US\$ } \\
\text { PPP }\end{array}$ \\
\hline 1980 & 5.4 & 328 & 4.3 & 262 & 1.1 & 66 \\
1981 & 5.6 & 367 & 4.4 & 289 & 1.2 & 78 \\
1982 & 5.7 & 402 & 4.5 & 319 & 1.2 & 83 \\
1983 & 5.8 & 426 & 4.9 & 362 & 0.9 & 64 \\
1984 & 5.6 & 436 & 4.6 & 357 & 1 & 79 \\
1985 & 5.5 & 455 & 4.4 & 369 & 1 & 86 \\
1986 & 5.4 & 472 & 4.3 & 377 & 1.1 & 95 \\
1987 & 5.5 & 526 & 4.4 & 419 & 1.1 & 107 \\
1988 & 6.1 & 637 & 4.8 & 505 & 1.3 & 133 \\
1989 & 6.3 & 712 & 4.9 & 557 & 1.4 & 155 \\
1990 & 6.7 & 813 & 5.3 & 640 & 1.4 & 173 \\
1991 & 6.9 & 917 & 5.3 & 711 & 1.5 & 206 \\
1992 & 7.2 & 990 & 5.6 & 766 & 1.6 & 224 \\
1993 & 7.5 & 1053 & 5.8 & 806 & 1.8 & 246 \\
1994 & 7.4 & 1055 & 5.6 & 797 & 1.8 & 258 \\
1995 & 7.6 & 1163 & 5.5 & 839 & 2.1 & 323 \\
1996 & 7.6 & 1217 & 5.5 & 880 & 2.1 & 336 \\
1997 & 7.5 & 1269 & 5.4 & 920 & 2.1 & 349 \\
1998 & 7.5 & 1353 & 5.4 & 976 & 2.1 & 376 \\
1999 & 7.5 & 1426 & 5.4 & 1028 & 2.1 & 398 \\
2000 & 7.5 & 1497 & 5.3 & 1073 & 2.1 & 424 \\
2001 & 7.5 & 1600 & 5.4 & 1143 & 2.1 & 457 \\
\hline
\end{tabular}

Source: OECD HEALTH DATA 2003 3rd ed. 
Table A2. Health expenditure layers 1980-2001

\begin{tabular}{|c|c|c|c|c|c|c|}
\hline & \multicolumn{2}{|c|}{$\begin{array}{l}\text { Public Expenditure in-patient } \\
\text {.care }\end{array}$} & \multicolumn{2}{|c|}{$\begin{array}{l}\text { Public Expenditure out-patient } \\
\text { care }\end{array}$} & \multicolumn{2}{|c|}{$\begin{array}{c}\text { Public Pharma. \& other medic } \\
\text { durables expenditure }\end{array}$} \\
\hline & $\begin{array}{l}\text { /capita, US\$ } \\
\text { PPP }\end{array}$ & $\%$ GDP & $\begin{array}{l}\text { /capita, US\$ } \\
\text { PPP }\end{array}$ & $\%$ GDP & $\begin{array}{l}\text { /capita, US\$ } \\
\text { PPP }\end{array}$ & $\%$ GDP \\
\hline 1980 & 144 & 2.4 & 55 & 0.9 & 44 & 0.7 \\
\hline 1981 & 159 & 2.4 & 61 & 0.9 & 48 & 0.7 \\
\hline 1982 & 175 & 2.5 & 65 & 0.9 & 54 & 0.8 \\
\hline 1983 & 209 & 2.8 & 72 & 1 & 56 & 0.8 \\
\hline 1984 & 207 & 2.7 & 70 & 0.9 & 54 & 0.7 \\
\hline 1985 & 207 & 2.5 & 75 & 0.9 & 58 & 0.7 \\
\hline 1986 & 208 & 2.4 & 77 & 0.9 & 56 & 0.6 \\
\hline 1987 & 233 & 2.4 & 80 & 0.8 & 63 & 0.7 \\
\hline 1988 & 261 & 2.5 & 104 & 1 & 88 & 0.8 \\
\hline 1989 & 297 & 2.6 & 103 & 0.9 & 93 & 0.8 \\
\hline 1990 & 347 & 2.8 & 118 & 1 & 104 & 0.9 \\
\hline 1991 & 400 & 3 & 119 & 0.9 & 120 & 0.9 \\
\hline 1992 & 436 & 3.2 & 128 & 0.9 & 132 & 1 \\
\hline 1993 & 466 & 3.3 & 130 & 0.9 & 137 & 1 \\
\hline 1994 & 460 & 3.2 & 131 & 0.9 & 142 & 1 \\
\hline 1995 & 471 & 3.1 & 138 & 0.9 & 159 & 1 \\
\hline 1996 & 492 & 3.1 & 142 & 0.9 & 173 & 1.1 \\
\hline 1997 & 506 & 3 & 148 & 0.9 & 192 & 1.1 \\
\hline 1998 & 532 & 2.9 & 155 & 0.9 & 205 & 1.1 \\
\hline 1999 & 553 & 2.9 & 164 & 0.9 & 222 & 1.2 \\
\hline 2000 & 572 & 2.9 & 169 & 0.8 & 234 & 1.2 \\
\hline 2001 & 604 & 2.8 & 180 & 0.8 & 251 & 1.2 \\
\hline
\end{tabular}

Table A3. Decomposition of the determinants of total Health Expenditure growth 19932001

\begin{tabular}{cccccccccc}
\hline Years & 1993 & 1994 & 1995 & 1996 & 1997 & 1998 & 1999 & $2000^{\mathrm{p}}$ & $2001^{\mathrm{p}}$ \\
\hline Total & $6.83 \%$ & $3.26 \%$ & $5.67 \%$ & $6.47 \%$ & $4.63 \%$ & $6.14 \%$ & $7.31 \%$ & $6.34 \%$ & $7.48 \%$ \\
Ageing & $0.81 \%$ & $0.79 \%$ & $0.77 \%$ & $0.78 \%$ & $0.83 \%$ & $0.93 \%$ & $1.09 \%$ & $1.33 \%$ & $1.41 \%$ \\
Utilisation & $5.09 \%$ & $-0.44 \%$ & $0.85 \%$ & $1.39 \%$ & $2.36 \%$ & $2.25 \%$ & $3.42 \%$ & $1.65 \%$ & $2.61 \%$ \\
Medical input prices & $-3.91 \%$ & $-1.38 \%$ & $-0.32 \%$ & $0.97 \%$ & $-0.61 \%$ & $1.42 \%$ & $-0.26 \%$ & $-0.69 \%$ & $0.56 \%$ \\
General inflation & $4.93 \%$ & $4.34 \%$ & $4.32 \%$ & $3.21 \%$ & $2.01 \%$ & $1.41 \%$ & $2.2 \%$ & $3.96 \%$ & $2.71 \%$ \\
\hline
\end{tabular}

Source: own calculation using Pellisé et al(2001) [15] methodology (base case). 
Table A4. Panel data results (GLS model): Determinants of public health care expenditure at the regional level (1992-1999)

\begin{tabular}{ccccc}
\hline & coef. & Std. Err. & coef. & Std. Err. \\
\hline Population & $-0.288^{* *}$ & 0.061 & $-1.037^{* *}$ & 0.312 \\
GDP & $0.331^{* *}$ & 0.058 & $1.071^{* *}$ & 0.070 \\
Ageing & $2 \mathrm{X} 10-5$ & $9 \mathrm{X} 10-5$ & $1.5 \mathrm{X} 10^{-4 * *}$ & $6 \mathrm{X} 10^{-4}$ \\
Occupancy & -0.007 & 0.004 & 0.001 & 0.002 \\
LOS & $0.321^{* *}$ & 0.096 & -0.044 & 0.153 \\
Beds & -0.008 & 0.025 & $0.049^{*}$ & 0.029 \\
Personnel & $0.173^{* *}$ & 0.063 & -0.106 & 0.094 \\
Intercept & $10.21^{* *}$ & 0.435 & $10.23^{* *}$ & 4.01 \\
Adj_R & 0.51 & & 0.91 & \\
F & 12.42 & & 146.55 & \\
Fixed Effects & No & & Yes & \\
\hline
\end{tabular}

Note: $*$ Significant at $10 \%, * *$ Significant at $5 \%$. 